\title{
The European approach to pensions and its impact on small self-administered schemes
}

Received: 5th June, 2004

\section{John Murray}

is a law graduate from Leeds University. He has been a partner at Nabarro Nathanson since 1986. He is a director of Eagle Place Trustees Ltd. Although his work covers the whole spectrum of pensions law including scheme documentation and scheme reorganisation, he has long been involved with small self-administered schemes having been accorded Pensioneer Trustee status by the Inland Revenue in 1982. He was elected to the Committee of the Association of the Pensioneer Trustees in September 2003, having previously been a member of the Committee from 1991 to 1997.

\begin{abstract}
Membership of the EU has had a significant impact on UK pension arrangements - directly from the Treaty in respect of equal treatment, as well as from the European Court of Justice (ECJ) in respect of the interpretation of aspects of the Treaty and also from Directives. This paper looks at some recent developments including two recently issued Directives which have already begun to have some impact in the UK, from the point of view of small self-administered schemes (SSAS).
\end{abstract}

Keywords: Europe; impact of case law; impact of demographics; European Directive on Activities and Supervision of Institutions for Occupational Retirement Provisions; small self-administered schemes (SSASs)

\section{Introduction}

Member states of the European Union have adopted a variety of approaches to occupational pensions and these were summarised in the European Commission's 1997 Green Paper. ${ }^{1}$ So, for example, in France the compulsory occupational pension scheme is 'pay as you go' and coverage is approximately 90 per cent of those in private sector employment, making up 21 per cent of all pension payments.

In Italy, coverage of supplementary schemes was about 5 per cent of private sector workers representing 2 per cent of total pension payout. In the Netherlands, occupational pension schemes, supplementary to the state scheme, account for about a third of all pension payments. In Germany, approximately 46 per cent of the total private sector employment is covered by occupational pension schemes which are partially book reserved and partially funded. Greece languishes with the Italians with coverage of 5 per cent of the total private sector whereas Denmark was approximately 80 per cent. The UK, at the same time the comparison was carried out, had 48 per cent of total private sector employees in occupational pension schemes.

The recent European Directive on Institutions for Occupational Retirement Provision emanated from the 1997 Green Paper. This began with a discussion of the demographic and economic context in which it was prepared. It emphasised the fact that the combined decline in birth rates and increased life expectancy were, as is well known, having considerable consequences. Much of the pressure of these consequences will fall 
on public social security pension schemes. These still account for by far the most significant proportion of pensions in Europe. So the combination of fewer births and longer life expectancy means that over time the ratio of those who have retired to those working will increase considerably. In 1997, there were approximately four people of working age to support each pensioner through social security contributions in the EU. However, by 2040 it is expected that those four people will have to support two pensioners and that for some member states the ratio will be even more uncomfortable. Much of the Green Paper was concerned with the prudent supervision of pension and insurance funds. Some readers may recall the efforts in the early 1990s of the European Commission to introduce a Directive. Indeed, the Association of Pensioneer Trustees (APT) was very concerned at that time about the possible impact of a draft Directive on the investment exemptions available to SSASs. The 1997 Green Paper has borne fruit - it will be interesting to see just how digestible this will prove to be.

\section{Previous impact of Europe on UK pension arrangements}

Although the attempts to produce a Directive in the early 1990s in the end were to no avail, Europe has had a significant impact on occupational and state pensions in the UK. Some of this has perhaps been a mixed blessing. The equal treatment requirements of the Treaty itself have had a major impact. It has certainly produced a good deal of work for those involved in the pensions industry.

In the late 1990s the Joseph Rowntree Foundation produced a brief report on the impact of EU law on pensions in the
$\mathrm{UK}^{2}{ }^{2}$ The report noted that EU activity in relation to occupational and state pensions was increasing. Much was directed towards creating the single market and avoiding distortions and competition. The report summarised some of the gains as including women's continued acquisition of occupational pension rights during maternity leave; equalisation of retirement and occupational pension age, enabling some women to enhance their entitlement by working to age 65 and the preservation rights acquired in one state scheme if a member moves to another member state. Among the adverse consequences identified by the Rowntree Foundation report was the fact that from 2010 , women have to wait until 65 for the same state pension.

Harmonisation is a key goal of the EU. The Rowntree Foundation report stated that upward harmonisation of EU state social security systems would be a more effective way of protecting the social security position of mobile workers. The report concluded that 'harmonisation is unlikely to be achieved in practice, however, since it would involve myriad and minute adjustments to each state system to neutralise the many differences between them in the light of other factors, such as taxation and the cost of living. Upward alignment of systems would also mean increased costs for some member states and maintenance of existing high levels of provision for others'.

Apart from the problem of increasing costs, the report highlighted the fact that member state autonomy is often invoked to explain why past attempts to secure member state agreement to harmonisation of state systems have failed. The report perceived one of the victims of this member state autonomy as being the draft Pension Fund Directive which was withdrawn in the early 1990s. 
The EU has not been daunted by those early setbacks and other Directives have managed to overcome the obstacles of member state autonomy. The ECJ too has recently played its role on the pensions stage.

\section{European Court of Justice judgments - Danner and Skandia}

The ECJ has been active on the pensions front in recent years. The Danner judgment of the European Court of Justice was given on 3rd October, 2002. ${ }^{3}$ The case concerned cross-border pension contributions between the European Community. Mr Danner held joint Finnish and German nationality. He had worked in Germany and contributed to two pension insurance schemes there. $\mathrm{He}$ then moved to Finland. He continued to contribute to the German schemes as well as the Finnish one. The Finnish tax authorities did not allow him to deduct his German contributions against his taxable income. Had those contributions been to a Finnish scheme he would have been able to do so. Article 59 (now in Arts 12 EC and 49 EC after amendment) of the EC Treaty precludes the application of any national legislation which has the effect of making the provision of services between member states more difficult than the provision of service purely within one member state.

The ECJ held that Art. 59 precludes a member state's tax legislation from restricting or disallowing the deductibility for income tax purposes of contributions to voluntary pension schemes paid to pension providers in other member states while allowing such contributions to be deducted when they are paid on the first member state, if that legislation does not at the same time preclude taxation of the pensions paid by the above mentioned pension providers.
What this means is that contributions to pension arrangements in other EC countries by UK tax payers must be treated in the same way as contributions to UK arrangements - unless the UK legislation does not impose a tax charge on the pensions arising from the EC contributions.

Skandia $v$ Ramstedt is a slightly more recent ECJ decision which follows the Danner judgment. This is another case that some commentators feel is providing an impetus towards pan-European pension schemes. Unlike Danner, it concerned the tax rules that apply to an insurance company rather than an individual. A Swedish insured fund can claim a tax deduction in Sweden at the time pension contributions were paid. On the other hand, a non-Swedish fund cannot claim the deduction until the benefits were paid. An insurance company brought the case against Sweden. Again, it was held that the member state's legislation was in breach of the EU Treaty.

\section{Infringement procedures opened by the Commission against the UK}

The European Commission issued a press release on 9th July, 2003. ${ }^{4}$ Apart from deciding to refer Denmark to the ECJ over discrimination, it also announced that it was going to open infringement procedures against the UK and Ireland. These proceedings can be quite time consuming as they involve three stages: a letter of formal notice from the Commission to the member state summarising the alleged infringement; reasoned opinion from the Commission to the member state setting out in more detail why the Commision considers there to be an infringement; and, ultimately, application to the ECJ in the event that the member state fails to 
comply with the reasoned argument. According to the press release:

'In both the UK and Ireland, the exemption from income tax of contributions paid by the employer in the hands of the employee and the deductibility of the employee's own contributions depends on the form of the pension arrangement (a trust) and the presence of a representative in the respective Member States to fulfil the administrative duties. The Commission has serious concerns about the compatibility of these tax rules with EU law and is therefore seeking more information from both Member States.'

The instituting of infringement procedures, together with the Institutions for Occupational Retirement Provision (IORP) Directive discussed below, has clearly influenced the UK government, in its tax simplification proposals, to decide that establishment of a trust will no longer be a pre-requisite for tax approval.

\section{Insurance mediation: Directive 2002/92/EC}

In the latter part of 2003 the FSA made contact with the APT and the SIPP Providers Group regarding the implications of the Insurance Mediation Directive. The Financial Services Authority (FSA) had received comments in connection with the guidance on insurance mediation. One of the main comments was that the guidance needed to say a lot more about the potential implications that implementation of the Directive may have on persons involved with pension schemes. There was certainly a concern that there may be implications for pension scheme trustees and administration companies that at that time had not been fully appreciated. Certain articles of the Regulated Activities Order have been affected by the Amending Order made under the Financial Services and Markets Act 2000. The concern of the FSA was that a new activity introduced by the Amending Order — assisting in the administration and performance of a contract of insurance - might apply to a paid pension scheme trustee if he were seen to be providing a service to co-trustees who were also policy holders. It was these concerns which led to discussions between the FSA and the representatives of the Self-Invested Personal Pensions (SIPP) Providers Group and the APT. In relation to SSASs, the main area of insurance concerns life insurance policies. In the context of a multi-trustee scheme (with a professional and paid pensioneer trustee) it seems from the discussions with the FSA that all trustees must process the relevant claim and it must be quite transparent that the pensioneer trustee is not remunerated for processing the claim.

\section{Institutions for Occupational Retirement Provision: Directive 2003/41/EC}

As mentioned above there has been comparatively little progress taken with regard to harmonisation of pension provision within the EU. The European Commission recognised that 'the general organisation of pension schemes, the choice of financing mechanisms and the practice arrangements for the operation of [funded occupational schemes] fall within the competence of the Member States as long as the Treaty rules are respected'. Other obstacles to harmonisation are differences in social security and labour practices and taxation in the EU. However, a step forward if not a leap forward - has been the Institutions for Occupational Retirement Provision Directive which was published in the Official Journal on 23rd September, 2003. ${ }^{5}$ Member states have two years 
within which to introduce the Directive directly into their own legislation. On 28th October, 2003, the Department for Work and Pensions (DWP) issued its consultation document on what it described as the 'Directive [which] will put in place a common framework that will allow cross border development of occupational pension schemes' ${ }^{6}$

The consultation document identified the key features of the Directive as including:

- recognising the diversity of national pension systems, leaving member states free to determine the structure of their own pension system;

— establishing the 'prudent person' principle in the management of pension schemes in the EU;

- establishing a common framework for pension schemes to operate cross-border. This will allow schemes established in one EU member state to be sponsored by employers in another member state;

- delivering some liberalisation of investment rules currently applied by some member states;

- establishing common funding principles for schemes; and

- setting out the minimum powers that every member state must give its regulator.

The APT sent in a response to the DWP making its contribution to the debate. ${ }^{7}$

Among its opening comments were echoes of some of the statements made in the early 1990s in relation to the draft Pension Fund Directive. In its response to the consultation paper, the APT stated:

'We acknowledge that the investment of pension funds needs to be on a prudential basis (a key feature of the Directive and, of course, a feature of UK Trust Law).
However, it has been established on previous occasions that it is not reasonable to impose the same investments restrictions that apply to large occupational pension schemes on small schemes, particularly where the members are also trustees and act together to run the scheme.

Without the investment flexibility offered by SSASs, many small businesses would be less likely to bother with private pension provision at all, preferring to see their business as their pension scheme.

Therefore, we [the APT] are strongly in favour of the UK Government adopting the exemption for small occupational pension schemes from all aspects of the Directive, other than, Article 19 (which we understand will apply to all schemes), particularly where all members run the scheme together.'

The APT response then went on to make specific comments on the consultation paper. Reference was made to the tax consultation paper ('Simplifying the taxation of pensions: the Government's Proposals'), published on 10th December, 2003, which proposed to abolish the role of the pensioneer trustee and which has since been overtaken by provisions in the Finance Bill. The response commented that the tax proposals are relevant as they are due to come into effect by 6th April, 2005 - before the UK is required to comply with the Pensions Directive. However, the effective date of the tax changes has now been put back to 6th April, 2006.

The APT response anticipated that there will be a continuing demand for trust-based schemes for a small number of individuals who are connected through family relationships or through being joint owner managers of businesses, whether employed or self-employed - whether pensioneer trustees continue as such in the future.

The APT report went on to state that those schemes would be able to operate 
on the basis that all members are involved (usually through being trustees) in all material decisions about the scheme. Like current SSASs, these will be schemes in which the value of protections afforded by the Directive for example, in relation to investments and the provision of information to members, was likely to be minimal and certainly less than the cost to those schemes of securing compliance. Conversely, the report considered the restrictions in the Directive on investment and borrowing to be inappropriate to these schemes, with their high degree of member control.

The APT response reiterated that it welcomed an exemption for schemes with fewer than 100 members. However, what if the DWP consider that an exemption for that number of members might be too wide? The APT response anticipated that possibility. The APT would be willing to support an exemption for schemes:

- having fewer than 100 members; and

— in which all members are trustees or their consent is required to any decision of the trustees (noting that this alternative was needed to cater for members who are bankrupt or otherwise incapable of being trustees);

- in which all decisions of the trustees must either be unanimous or take in a meeting of which all trustees have had reasonable notice.

The APT considered it reasonably certain that Art. 5 allows the UK to exempt some schemes with fewer than 100 members and not exempt others. This could be structured as:

- choosing to exempt all such schemes under Art. 5; and

- voluntarily applying equivalent provisions to those in the Directive to some of those schemes purely as an exercise of domestic legislative power. The APT response notes that an individual or a company acting as a pensioneer trustee may act as a trustee of anything from one to several thousand schemes.

The response highlighted a concern as to whether a pensioneer trustee, or a scheme having a pensioneer trustee, would be able to take advantage of any small schemes exemption.

It was noted that the consultation paper took the view, which the APT supports, that the concept of the IORP can be equated with the scheme itself. If any small scheme exemption were to be based purely on the number of members in a particular scheme, that would not cause pensioneer trustees undue concern.

The APT response recognised that a pension scheme itself has no legal personality. It may be, therefore, that the UK government eventually takes the view that the UK implementation of the Directive will be based on application to the trustees of the scheme. In those circumstances, the APT response asked that, for the purposes of any small schemes exemption, it is made clear that it is the body of trustees as a whole, rather than any single trustee, that is regarded as the IORP. The implication of that is essentially two-fold. First, a pensioneer trustee who is one of several trustees of any particular scheme would not be an IORP on his own: he would only satisfy the description of an IORP when considered as part of the body of trustees in the particular scheme.

Secondly, it would follow that there would be no aggregation of the members of different schemes to which the pensioneer trustee is appointed, so the fact that a pensioneer trustee may be appointed to, say, 20 different schemes, each having other trustees and each 
having six members, does not spoil the small schemes exemption for each of their schemes.

The APT response on the Pensions Directive was that the preservation of the exemption was appropriate for two main reasons. First, the pensioneer trustee will generally take a quite limited role in the administration of each scheme; his core role is to see that the Inland Revenue's requirements are met. However, fulfilling that role does not of itself mean that the schemes will be administered in common or will in any way achieve the economies of size that make it appropriate to apply the Directive to larger schemes. Secondly, by their nature, schemes to which the Inland Revenue require a pensioneer trustee to be appointed are likely to be schemes in which there are few members and those members are, or are closely connected with, the trustees of the scheme and so do not require the same degree of protection from abusive control of the scheme and its investments.

\section{Conclusion}

The draft Pensions Directive of the early 1990s was ill fated. However, the IORP Directive has succeeded. That and the combination of the ECJ decisions and the infringement procedures show the EU flexing its muscles on pensions matters. The final impact of this combination on SSASs will be interesting to observe in the coming months and years allied to the impact of the UK government's proposals in the Finance Bill for pensions simplification (which have, of course, been drafted with an eye on EU developments).

\section{References}

1 'Supplementary Pensions in the Single Market - A Green Paper', Brussels, 10.06.1997 COM (97) 283.

2 'The Impact of European Union Law on Pensions in the UK', published in Findings - Social Policy Research 102, September 1996, Joseph Rowntree Foundation, York.

3 Danner [2002] 53 PBLR, Shandia v Riksskatteverhet [2003] 46 PBLR.

4 'Pensions Taxation: Commission Decides to Refer Denmark to Court over Discrimination and to Open Infringement Procedures Against the UK and Ireland', press release IP/03/965, 9th July, 2003, available at http://europa.eu.int/secretariat_general/ $\mathrm{sgb} /$ droit_com/index_en.htm

5 'Institutions for Occupational Retirement Provision Directive', Official Journal, 23rd September, 2003, L235/10-20.

6 Department for Work and Pensions (2003) 'Implementing the European Directive on Activities and Supervision of Institutions for Occupational Retirement Provision: A Consultation Paper', 28th October, available at www.dwp.gov.uk/ resourcecentre/consultation_papers.asp.

7 Association of Pensioneer Trustees (2003) 'Response of the Association of Pensioneer Trustees to the Department for Work and Pensions', 23rd December. 